\title{
Non-standard methods in the privatiz- ation strategies of the Czech Republic, Hungary and Poland ${ }^{1}$
}

\section{Morris Bornstein}

\author{
Department of Economics \\ University of Michigan \\ Ann Arbor, \\ Michigan 48109-1220, USA \\ Tel: (1) 3137634153 \\ Fax: (1) 3137642769 \\ E-mail: morborn@umich.edu
}

\section{Abstract}

The Czech Republic, Hungary and Poland followed different strategies in the use of nonstandard methods of privatization. In regard to restitution, the Czech Republic carried out physical return of property, Hungary weakly implemented financial compensation and Poland has not yet approved a programme. Management and employee buyouts were eschewed in the Czech Republic, took the form of employee stock ownership plans in Hungary and were accomplished chiefly by lease-purchase in Poland. The Czech mass privatization programme distributed a considerable amount of joint-stock company shares free through voucher auctions in which citizens participated directly or through financial intermediaries. In contrast, the Polish programme provided citizens free shares in investment trusts that exercise corporate governance over operating companies and restructure them for divestiture. Hungary's programme, which offered people only interest-free loans to buy some shares in initial public offerings, was abandoned soon after its start.

JEL classification: D63, G30, H82, L33, P52.

Keywords: privatization, restitution, management and employee buyouts, voucher auctions, investment funds, share ownership.

\section{Introduction}

Three Central European countries-the Czech Republic, ${ }^{2}$ Hungary and Poland-are leaders in privatization, with some similarities and many important differences among 
them in the approaches to and results of, privatization. This study compares their use of three 'non-standard' methods of privatization: restitution, management and employee buyouts and 'mass' privatization. ${ }^{3}$ The final section draws some general conclusions.

\section{Restitution}

Restitution entails redress by the state for expropriations of property deemed unjust because they were carried out under improper legislation or in violation of prevailing proper legislation. $^{4}$

After restitution has been accepted in principle, the design of a restitution programme must consider various aspects, such as the period of expropriation, the type of assets, the eligibility of claimants and the form of redress. The Czech Republic, Hungary and Poland differ considerably in their approaches to these issues.

\subsection{The Czech Republic}

Of the three countries, the Czech Republic has the strongest restitution programme. Proponents advocated restitution (a) on moral grounds to redress egregious past injustices; (b) for psychological reasons to restore public confidence in the legal protection of private property; and (c) as a simple and quick way to privatize some kinds of property. Opponents argued that restitution of property was a selective attempt to achieve justice retroactively and did not redress what the population had lost-in liberty, careers and lives-under 40 years of Communist rule. Also, they asserted that restitution would, in fact, delay privatization of property, because the claims process would be lengthy. Parliament chose, nevertheless, to adopt a broad restitution programme, described below (Cepl, 1992; Pehe, 1994).

\subsection{Hungary}

There were three main factors favouring restitution in Hungary. First, it was deemed a moral obligation. Second, state assets could not be divested so long as their ownership was subject to legal dispute. Third, as a condition of its continued participation in the government's centre-right coalition bloc, the Smallholders Party demanded restitution of agricultural land (Mihályi 1994, p.365). However, the positions of other political parties differed widely-ranging from support for financial compensation for more types of expropriated assets at one end of the spectrum, to opposition to any restitution programme at the other end. After two years of parliamentary debate and rulings by the Constitutional Court (Comisso, 1995), Hungary adopted a modest restitution programme, which was only partly implemented.

\subsection{Poland}

Poland still has no restitution programme, because of controversies among political factions about the possible contours of a programme (Kwiecinski and Baehr, 1995; interviews carried out by the author). ${ }^{5}$ Proponents support restitution on moral grounds to redress past injury; on legal grounds to show respect for private property; and on economic grounds to help provide the private ownership needed for a competitive market economy. Opponents present three main arguments. First, the small minority of people who are ex-property owners should not get restitution when the population as a whole receives no compensation for the freedom and consumption lost during decades of communist rule. Second, restitution would reduce potential budget revenue if the state 
divests for restitution property that might otherwise be sold. Third, the possibility of physical restitution could delay privatization by creating uncertainty about ownership.

\subsection{Comparisons}

The three countries differ in many aspects of restitution (see Table 1).

Table 1. Restitution programmes

\begin{tabular}{|c|c|c|c|}
\hline Aspect & Czech Republic & Hungary & Poland \\
\hline $\begin{array}{l}\text { Programme } \\
\text { approved }\end{array}$ & Yes & Yes & No \\
\hline $\begin{array}{l}\text { Period of } \\
\text { expropriation }\end{array}$ & $\begin{array}{l}\text { Communist regime after } \\
\text { February } 251948\end{array}$ & $\begin{array}{l}\text { Since } 1939 \text {, including } \\
\text { fascist, pre-Communist, } \\
\text { and Communist regimes }\end{array}$ & \\
\hline Type of assets & Real property & Real property & \\
\hline Status of claimant & $\begin{array}{l}\text { Natural persons who are } \\
\text { resident citizens }\end{array}$ & Natural persons & \\
\hline Form & $\begin{array}{l}\text { Return of physical } \\
\text { property, except in special } \\
\text { cases }\end{array}$ & Compensation certificates & \\
\hline Implementation & Mostly completed & Only partly implemented & \\
\hline
\end{tabular}

\subsubsection{Period of expropriation}

The central question is whether restitution should cover expropriations under not only Communist but also non-Communist governments.

The Czech restitution programme pertains to confiscations after the Communist seizure of power on February 28 1948, but excludes (a) Jewish property seized by the Nazis after 1938; (b) the firms (in industry and finance, with more than 500 employees) nationalized by the democratically-elected government during 1945-48; and (c) property of the three million Sudeten Germans expelled in 1945-46.

In Hungary, the government proposed that restitution apply to expropriations after the Communist accession to power on June 8 1949. However, the Constitutional Court held that this cut-off date was arbitrary and that earlier 'unjust' expropriations should also be redressed. Thus, the restitution programme was extended to 1939, to cover actions by the Horthy regime and the pre-Communist government after World War II.

In Poland, most supporters of restitution favour covering nationalizations during 1944-62. Others would extend the starting date to September 1 1939, to also embrace property abandoned in areas that do not belong to the current Republic of Poland and Jewish property confiscated by the Nazis and later nationalized by the Communists.

\subsubsection{Type of assets}

The main issue is whether restitution should cover only real property (land, buildings and equipment) or also movable physical property and financial assets. The Czech Republic and Hungary chose (and Poland may select) real property only, because of the difficulties involved in proving the confiscation of the other two categories and establishing current values for them. 


\subsubsection{Status of claimant}

The Czech programme offers restitution to natural persons, including heirs, who are resident citizens, and Polish restitution proposals would do the same. In contrast, the Hungarian restitution programme covers natural persons including ex-Hungarians living abroad. $^{6}$

\subsubsection{Form of restitution}

The three chief possible forms of restitution are (a) 'physical' restitution of the same property confiscated; (b) a cash payment; and (c) coupons to bid in auctions of state property.

The Czech parliament strongly preferred physical restitution, because it feared that if restitution were made by other methods the property might go mainly to members of the former Communist nomenklatura with funds to buy it (with cash or coupons acquired for cash) ${ }^{7}$ Hence, physical restitution is the basic method, with financial compensation used only in special cases. ${ }^{8}$

In Hungary the Constitutional Court required a single and uniform method of redress-return of physical property or financial compensation-for all expropriated property. Because physical restitution was not possible for all expropriated property, only financial compensation is offered. It is both partial and regressive, covering a smaller percentage of damages, the greater their amount-up to a maximum award of 5 million Hungarian forints (HUF), equivalent to about US\$ 67,000 at the average 1991 exchange rate. Compensation is paid in freely tradable certificates that can be used to buy state assets offered for these certificates or (in the case of elderly people) a life annuity from the state.

In the Polish debate about restitution, the most popular form is similar to the Hungarian variant: partial financial compensation, on a regressive scale, in certificates to buy state property.

\subsubsection{Implementation}

Adequate statistical data are lacking about the Czech programme, because restitution claims are supposed to be settled between the former and present owners, with no direct role for government authorities. By one estimate, the restitution programme covered no more than 10 per cent of former private property, chiefly because of the exclusion of expropriations in 1945-48 (Bouin 1993, pp.120-22). According to another estimate, 1025 per cent of all state-owned apartment housing and retail shops-much more than originally expected-were privatized by the return of the physical properties (Kotrba and Svejnar, 1994, p.154). Thus, it is widely agreed that restitution was a significant element in 'small-scale' privatization.

The key problem of the Hungarian restitution programme is that the government has not made enough property available for purchase with compensation certificates, preferring instead to sell property for cash and to strategic (rather than small) investors. For example, by August 1995 the face value of certificates issued was HUF 129 billion and their nominal value, plus capitalized interest, was HUF 220 billion, but only HUF 67 billion of certificates-less than one-third-had been used for share purchases and all other privatization transactions and an insignificant amount for life annuities ('Compensation Scene', 1995). Certificates have been traded at a big discount from the sum of their face value plus capitalized interest. In 1993, the discount was about 50 per cent, but by late 1995 it reached 80 per cent. Holding certificates has been a risky speculation that the Hungarian government might, in the future, make enough assets available to fulfil its legal obligations for restitution.

In Poland so far no restitution programme has been adopted, for two main reasons. 
First, there is no politically strong interest group pressing for restitution. Second, the government has opposed any restitution programme that could significantly reduce budget revenue-through return rather than sale of state property, or through its sale for compensation vouchers instead of cash.

\section{Management and employee buyouts}

In an employee buyout (EBO), employees of a state-owned enterprise (SOE) being privatized acquire the shares of the firm, or its assets to form a new company. The number of shares bought by each person, with own and borrowed funds, can vary according to length of service, position and pay.

Management buyouts (MBOs) and combined management and employee buyouts (MEBOs) are more likely than EBOs to control labour costs, modernize and expand the capital stock and adjust output. MBOs by a small group of insiders may be politically less acceptable than broader MEBOs. An MEBO may formally be an EBO, though with the management group holding a controlling (but often minority) block of shares, which it seeks to increase through purchases of shares from workers.

The government may use MEBOs as a method of privatization for several reasons. First, it can thereby recognize that employees had some property rights in SOEs, particularly if enterprise councils exerted influence over decisions on employment and the disposition of profits. Second, insider privatization through MEBOs avoids resistance from managers and workers to outsider privatization that could threaten job security. Third, the government may consider MEBOs simpler and faster than possible alternative methods, such as sales to outsiders by auction, public tender or direct negotiation.

The Czech Republic, Hungary and Poland differ significantly in regard to EBOs, MBOs and MEBOs.

\subsection{The Czech Republic}

In the Czech Republic, EBOs were opposed for two main reasons (Charap and Zemplinerova, 1994b, pp.141-47; interviews carried out by the author). First, employeecontrolled enterprises would devote revenue to labour compensation rather than reinvestment. Second, it would be unfair to treat employees of any SOEs differently than the rest of the population. In turn, MBOs would favour the present managers, usually members of the former Communist nomenklatura. Thus, neither EBOs nor MBOs are specifically mentioned in Czech privatization legislation.

\subsection{Hungary}

In contrast, through 1992 legislation ${ }^{9}$ Hungary explicitly encouraged the formation of EBOs (which actually were MEBOs) as a way of speeding the privatization of smaller SOEs in a 'democratic' way through closed tenders (Karsai, 1994; Boda and Neumann, 1994; interviews carried out by the author). The Employees' Part-Ownership Programme provided a very general framework for an employee stock ownership programme, or ESOP (Nemes, 1995). If at least 40 per cent of the employees (including managers) of an SOE favour formation of an ESOP and at least 25 per cent agree to participate in it, the SOE may be sold to a new entity in which the ESOP holds a majority of shares.

\subsection{Poland}

In Poland, support for EBOs as a privatization method has roots in the workers' self- 
management movement associated with enterprise councils during the 1980s. However, policy-makers in the post-Communist governments in 1989-93 had misgivings about both workers' councils and employee ownership. Thus, although Polish privatization legislation created various possibilities for employee ownership of shares in privatized enterprises, only one privatization method facilitated MEBOs (Woodward, 1995, pp.329-31; Szomburg and Tamowicz, 1994, pp.175-76).

The 1990 Law on Privatization of State-Owned Enterprises authorized two main methods of privatization, commonly referred to in Poland by the misleading names of 'capital privatization' and 'liquidation privatization'.

In capital privatization, an SOE is transformed (corporatized ${ }^{10}$ ) into a joint-stock company (JSC), some or all of whose shares are sold to private investors through initial public offerings (IPOs), tenders, or direct negotiation. Corporatization abolished enterprise councils through which workers had influenced employment and compensation, selection of enterprise managers and the firm's investment policy. To get their acquiescence to this loss of property rights in the enterprise, employees were offered the opportunity to buy up to 20 per cent of the JSC's shares at half price. In addition, employees could buy shares in their enterprises on the same terms as outsiders. Although these provisions of the so-called 'capital track' could generate widespread employee ownership of a limited amount of shares in privatized SOEs, they were not intended to lead to EBOs in which employees owned enough stock to control firms. There were only a few companies in which employees acquired full or dominant ownership of shares.

In Polish legislation there are two types of 'liquidation' of state enterprises. Article 19 of the 1981 Law on State Enterprises covers liquidation in the conventional sense of bankruptcy, when an insolvent SOE is closed and its assets sold. Article 37 of the 1990 Law on the Privatization of State Enterprises provides for liquidation in which a solvent SOE ceases to exist and its assets are leased, sold, or otherwise 'contributed' to a new private company. The enterprise's legal status changes from an SOE to a private firm, but its assets remain and its operations continue. Of the three techniques, leasing to an MEBO is the main form of liquidation under Article 37.

\subsection{Comparisons}

Table 2 compares principal features of MEBOs in the three countries.

\subsubsection{Form}

In the Czech Republic only a small fraction of approved privatization projects for an SOE formally involved MBOs. More often, an MBO occurred when an SOE was acquired through a 'front' company including, along with the SOEs management, outside investors. In Hungary, the buyout is formally an ESOP EBO, but actually an MEBO under the leadership of the management of the former SOE. In Poland, the buyer is an MEBO in which more than half of the former SOEs employees are shareholders.

\subsubsection{Company size and branch distribution}

In all three countries, the buyouts have occurred in small or medium-sized companies, chiefly in trade, services and light industry-in which asset values are small enough that an $\mathrm{MBO}$ or MEBO, with own and borrowed funds, may be feasible.

\subsubsection{Financing}

Czech MBOs were financed largely by outside investors, often from bank credit.

In Hungary, an ESOP acquires its shares partly with a nominal cash down payment from participating employees, ${ }^{11}$ but mostly with bank credit for the rest of the purchase 
price on easy terms: a below-market interest rate, a maturity up to 15 (though commonly 5-8) years and a 3-year grace period before the start of principal repayments. Collateral for the loan is usually the company's real-estate. Interest and principal payments on the loan come from the firm's profits and these payments are fully exempted from the company income tax.

Table 2. Management and employee buyouts

\begin{tabular}{|c|c|c|c|}
\hline Aspect & Czech Republic & Hungary & Poland \\
\hline Specific legislation & No & Yes & Yes \\
\hline Form & MBO & $\begin{array}{l}\text { Formally ESOP; } \\
\text { EBO, actually } \\
\text { MEBO }\end{array}$ & MEBO \\
\hline Company size & Small to medium & Small to medium & Small to medium \\
\hline Branches & $\begin{array}{l}\text { Trade, services, light } \\
\text { industry }\end{array}$ & $\begin{array}{l}\text { Trade, services, light } \\
\text { industry }\end{array}$ & $\begin{array}{l}\text { Trade, services, light } \\
\text { industry }\end{array}$ \\
\hline Financing & $\begin{array}{l}\text { Bank credit to 'front' } \\
\text { company }\end{array}$ & Bank loan to ESOP & Lease-purchase \\
\hline Control of firm & Management & Management & Management \\
\hline Main problem & Acquisition debt & Acquisition debt & Acquisition debt \\
\hline $\begin{array}{l}\text { Relative importance in } \\
\text { privatization } \\
\text { programme }\end{array}$ & Negligible & Minor & Significant \\
\hline
\end{tabular}

In contrast to the reliance on bank credit in the other two countries, in Poland the buyout, typically, is a lease-purchase agreement between the new private company and the SOE's 'founding body', ordinarily a ministry or local government. The lease contract includes a down payment of 20 per cent of the book value of the liquidated SOE and payment (from profits) of the balance over 5-10 years. The lessee gets title to the assets after payment of half of the lease amount.

\subsubsection{Control}

Management controls the firm not only in the Czech MBOs, but also in Hungarian and Polish MEBOs. In the Hungarian and Polish buyouts, managers may hold only about one-fourth of the shares, but their control of the firm is usually not challenged by the workers, who as a group hold a majority of the shares.

\subsubsection{Main problem}

In the three nations, the buyouts are often burdened by acquisition debt. ${ }^{12}$

In the Czech Republic many MBOs cannot make scheduled payments of interest and principal on the initial credit for privatization and subsequent loans for restructuring and they face bankruptcy (interview carried out by the author).

In Hungary (Boda and Neumann, 1994; Karsai, 1994; interview carried out by the author), many of the ESOP enterprises were barely profitable at the time of privatization. Because of large borrowings for the buyouts, these firms could not subsequently get enough additional credit to restructure inputs and output. Hence, the companies do not 
earn enough profit to start repayment of principal at the end of the 3-year grace period. Many of the ESOP firms will probably go out of business, but some may be rescued through take-overs by venture capitalists.

In Poland the financial condition of MEBOs varies considerably. In 1995, about 60 per cent were financially sound, but only 20 per cent had good prospects for future development (Rapacki, 1995, p.68). The stronger MEBOs are usually medium-sized firms (with over 300 employees) in industry. The weaker MEBOs are typically small firms (with less than 100 employees) operating in a competitive environment in trade (Filatotchev et al., 1996, p.74). Many MEBOs have difficulty getting bank credit for fixed investment and working capital. One reason is the commitment to devote profits to paying off leased assets. Also, MEBOs cannot pledge real-estate as collateral for bank loans until ownership title to assets moves from the state to the MEBO. Finally, there is some uncertainty about the validity of ownership title as long as restitution claims are not resolved. Most MEBOs have carried out little capital investment and some have even sold fixed assets in order to finance working capital needs.

\subsubsection{Relative importance in privatization programme}

Although national statistics do not provide fully comparable data for the three countries, it is clear that the relative importance of buyouts varies across the three countries, from negligible in the Czech Republic to significant in Poland. In the Czech Republic, (formal) MBOs accounted for only 6 per cent of the units and 2 per cent of the book value of property privatized by the end of 1992 (interview carried out by the author). In Hungary, companies divested through ESOPs constituted 23 per cent of the number of enterprises privatized, but only 7 per cent of the book value of privatizations by March 311995 (interview carried out by the author).

Polish privatization statistics usually report the number of enterprises concerned, rather than their assets (at book or market value). By the end of 1995, 1,581 SOEs were privatized, including 159 by the capital track, 383 by insolvency under Article 19 and 1,039 by liquidation under Article 37. MEBOs under lease contracts constituted 48 per cent of the grand total and 73 per cent of the liquidations under Article 37 (Rapacki, 1996).

\section{Mass privatization}

In contrast to selective free transfer through restitution and selective (preferential) sale through management and employee buyouts, mass privatization (MP) entails general free transfer of a portion of state assets to (potentially) all of the citizens of the country. 'Mass' refers to the universal and uniform opportunity for citizens to acquire property divested under an MP programme. The term does not imply that all, or most, of state assets will be privatized by MP.

The three countries covered in this study took very different approaches to MP. The Czech Republic provided voucher coupons to bid in auctions of company shares. Hungary offered citizens only interest-free loans to buy shares in designated enterprises. Poland gave people free shares in investment trusts controlling operating companies.

\subsection{The Czech Republic}

In the Czech Republic, advocates supported MP for a variety of reasons (Mejstrik and Burger, 1994; interviews carried out by the author). (1) MP was deemed essential because, in 1991, the personal savings of the population were less than one-fourth the 
book value of the approximately 5,000 enterprises that might potentially be included in a 'large-scale' privatization effort (Charap and Zemplinerova, 1994b, p.157): (2) Enterprises should be restructured by new private owners after privatization, rather than by the government before privatization. By hastening privatization, MP would hasten restructuring. (3) Managers who feared loss of control over firms would resist MP, leading to dispersed ownership, less than privatization by sale to outside 'core' investors. (4) MP would be more transparent and fairer than, for instance, privatization by closed tenders or direct negotiation. (5) MP through voucher auctions would educate people about investment choice in a market economy and stimulate the development of a capital market. (6) MP would gain popular support for privatization and for the government in the next general election.

MP was opposed on several grounds. (1) Wide dispersion of ownership under MP would lead to weak corporate governance. (2) Organisation of voucher auctions would be a daunting administrative task. (3) The state would receive no budget revenue from the assets divested through MP.

The government undertook MP through voucher auctions in the belief that free transfer of assets was necessary for speedy privatization, that the consequences for corporate governance were not serious, ${ }^{13}$ and that the loss of budget revenue was not important when the country had no budget deficit problem.

\subsection{Hungary}

In Hungary, there was modest support for MP on several grounds (Major, 1994, p.117). (1) Domestic individual and institutional demand for state property was small relative to the amount of assets to be divested. (2) In the first two years of post-Communist privatization (1990-91), over 70 per cent of privatized property was acquired by foreigners-leading to criticism of a 'sell-out' of national wealth. (3) Broad participation in the privatization process would build public confidence in and support for, privatization. (4) By making millions of Hungarians 'private owners', MP could help fulfil the desire of the leading party in the government coalition to create a 'new national and Christian middle class'. (5) MP would thus gain votes in the next parliamentary election for the government coalition parties, which were losing popular support. (6) MP could help develop the capital market by increasing the number of companies listed and the value of shares traded, on the Budapest Stock Exchange.

Opponents of MP had several objections (Major, 1994, p.140). (1) 'Free distribution' of assets was inconsistent with the principles of a market economy, in which wealth is accumulated by saving from income and property is bought and sold, not given away.

(2) Property distributed free would be used less effectively than purchased property. (3) In the short term, inflation might increase if people receiving free 'property coupons' sold them for cash and spent the money on consumption. (4) With the International Monetary Fund pressing Hungary to reduce its budget deficit, the country could not sacrifice revenue by giving state assets away instead of selling them.

After several years of debate by politicians and economists, the government approved a weak version of MP called the Small Investors' Share Ownership Programme (SISOP). Under it the state would sell to small investors on favourable terms a block of 5-15 per cent of the shares in IPOs of about 70 SOEs to be privatized.

\subsection{Poland}

In Poland, discussion about MP began in 1988 and ultimately focused on a specific proposal in 1991 by Janusz Lewandowski, then Minister of Privatization, for a Mass Privatization Programme (MPP) along the following lines (Gomulka and Jasinski, 1994, pp.220-25, 236-37). Hundreds of larger SOEs should be corporatized and their shares 
allocated in three ways: 15 per cent given free to employees; 60 per cent transferred free to 15 investment trusts called National Investment Funds (NIFs); and 25 per cent retained by the State Treasury. Each NIF should control a set of the operating companies (OCs) included in the programme and should eventually sell (some) OC shares, perhaps after restructuring the OCs. Each NIF should be run by a private management firm (MF) owned by a consortium of several Polish and foreign management and banking companies. For a nominal fee, Polish citizens could acquire a tradable ownership certificate in each NIF.

Supporters of such an MPP presented several arguments (Blaszczyk, 1995, pp.80-81; interviews carried out by the author). (1) There was a significant set of SOEs which had to be corporatized, because they were too large to be privatized by direct sale to strategic investors or by leasing to MEBOs. (2) But the shares of most of these enterprises could not be sold on the capital market, because the firms were in poor financial condition. In some cases they were companies with good longer-term prospects that were temporarily in distress. (3) Thus, a large group of SOEs needed restructuring before privatization, for which the staff of the Ministry of Privatization was not qualified. The task required the expertise and resources of an MF of the kind proposed. The MPP solved the problem of corporate governance by placing control of each OC in the hands of one NIF and assigning the direction of each NIF to a qualified MF. (4) This approach was strongly endorsed by the World Bank and the International Monetary Fund as a condition of their assistance to Poland and the World Bank and the European Bank for Reconstruction and Development offered loans to support such an MPP. (5) The MPP treated all Polish citizens fairly by offering them an identical portfolio of share certificates in NIFs. (6) Thus people unfamiliar with capital markets would be spared the need to directly choose shares in individual OCs.

However, the MPP was opposed on various grounds (interviews carried out by the author). (1) For budgetary reasons, the state should try to divest at least some of the shares of some of the OCs by sales to commercial investors or equity-for-debt swaps for part of Poland's domestic and foreign debts. (2) If control of those OCs could be divested, restructuring could be left to the new private owners. (3) Citizens had no choice about the assets they received under the MPP. (4) The MPP was too complex for many people to understand. Some might not participate at all. Others, especially the poor, might sell their certificates (to more affluent people who might instead have bought OC shares if available) and spend the proceeds on personal consumption.

After two years of debate the MPP was approved by the Polish Parliament in 1993, but political controversy about it continued and its implementation did not begin until 1995.

\subsection{Comparisons}

Table 3 compares main elements of MP in the three countries.

\subsubsection{Distribution mechanism and portfolio choice}

In the Czech Republic, for a nominal fee of 1,000 korunas (Kcs), equivalent to about US $\$ 35$, each adult citizen could buy a book of vouchers (with 1,000 'investment points' in 10 coupons of 100 points) to bid in auctions of shares in privatized JSCs. About 80 per cent of the eligible people obtained the books. Voucher auctions were carried out in 'waves' and 'rounds' (Kotrba and Svejnar, 1994, pp.166-80). Wave 1 covered 59 per cent of the JSCs and 62 per cent of the shares involved in voucher privatization and Wave 2 the rest. The iterative process included 5 'rounds' in Wave 1 in 1992 and 6 rounds in Wave 2 in 1994 (delayed from 1993 because of the split of Czechoslovakia into the Czech and Slovak Republics). In these auctions, the state set and adjusted the 
prices (in investment points) and the buyers bid the quantities (of shares) they wanted at those prices-the reverse of the usual auction procedure in which the seller specifies the quantity and the buyer the price. The auction process proceeded smoothly and was considered transparent and fair (Shafik, 1995).

In Hungary, every resident citizen 18 years of age or older could qualify for SISOP by paying a registration fee of HUF 2,000 (about US $\$ 22$ ). The person would get an interest-free loan ('instalment payment facility') of HUF 100,000 (about US $\$ 1,100$ ) that could be used to buy SISOP IPO shares, which would be pledged as collateral for the credit. The loan would be repaid in five annual instalments, with each instalment constituting complete payment for a proportional part of the shares (KRP, 1995).

In Poland, for a fee of PLZ 20 (about US\$ 8) every resident Polish citizen 18 years of age or older could get one master share certificate (MSC) representing proportional ownership in all the NIFs. Subsequently, after NIFs issue prospectuses following an audit of their accounts, the MSC may be exchanged for one separate share in each of the 15 NIFs. Both the MSC and the NIF shares may be freely traded. However, unlike the Czech and Hungarian programmes, the Polish MPP does not distribute shares in the OCs themselves.

The three programmes also differ in the initial portfolio choices afforded each participating citizen. In the case of the Czech Republic, a person had three sets of options: (a) to what extent to bid voucher points directly for OC shares or to turn points over to intermediaries to do so; (b) at what prices to bid directly for shares in which OCs; and (c) which intermediaries to use instead of participating directly in the auctions. In the Hungarian SISOP, the choices available to citizens concerned (a) the size of the loan to take and (b) which OC shares to buy with it. In contrast, the Polish MPP provided no choice at all: everyone got the same MSC, to be converted into the same set of NIF shares.

\subsubsection{Investment funds and corporate governance}

The three countries differed sharply in the role assigned to investment funds (IFs) as intermediaries for the population as ultimate recipients of state property.

In the Czech Republic, IFs were not included in the government's original MP plan, which expected that voucher privatization would lead to dispersed individual ownership of JSC shares privatized by voucher auctions. Therefore, it was a surprise, not the intentional result of clever design, that about 450 IFs emerged to collect about two-thirds of the voucher points and that a small subset of them obtained a lot of the points. For example, in Wave 1 the 14 largest IFs got 78 per cent of the points invested through IFs and 58 per cent of all points invested. In Wave 2, the corresponding percentages were 60 and 38 (Lieberman et al., 1995, p.76). Studies of samples of JSCs show that, in many firms, one IF holds 20 per cent of the shares and that in other JSCs 2-4 IFs together hold a controlling minority, if not an absolute majority of the shares (Lastovicka et al., 1995). Thus, IFs, separately or together, can play an important role in corporate governance of JSCs.

In the Hungarian SISOP, IFs were not envisaged (and did not emerge). The government expected that strategic investors would buy most of each IPO and control the privatized firm.

In contrast, the NIFs have a decisive role in the Polish MPP. The bulk, 60 per cent, of each OCs shares was given free to the 15 NIFs, with one ('lead') NIF receiving 33 per cent and the other 14 NIFs together the balance of 27 per cent (for an average of about 2 per cent per non-lead NIF). A lead NIF exercises corporate governance over the OCs in which it holds a controlling (though minority) block of shares. 
Table 3. Mass privatization programmes

\begin{tabular}{|c|c|c|c|}
\hline Aspect & Czech Republic & Hungary & Poland \\
\hline $\begin{array}{l}\text { Distribution } \\
\text { mechanism }\end{array}$ & $\begin{array}{l}\text { Free vouchers to bid in } \\
\text { auctions of OC shares }\end{array}$ & $\begin{array}{l}\text { Shares in IPOs to be } \\
\text { bought over } 5 \text { years with } \\
\text { interest-free credit }\end{array}$ & $\begin{array}{l}\text { Free share certificates } \\
\text { in NIFs, to which } 60 \\
\text { per cent of OC shares } \\
\text { transferred }\end{array}$ \\
\hline $\begin{array}{l}\text { Portfolio of choice of } \\
\text { participating } \\
\text { citizens }\end{array}$ & $\begin{array}{l}\text { Bid voucher points } \\
\text { directly for chosen OC } \\
\text { shares, or give voucher } \\
\text { points to chosen IFs to } \\
\text { bid }\end{array}$ & $\begin{array}{l}\text { Size of loan and which } \\
\text { OC shares to buy }\end{array}$ & None \\
\hline $\begin{array}{l}\text { Investment funds } \\
\text { (IFs) }\end{array}$ & About 450 private IFs & None & $\begin{array}{l}15 \text { government-created } \\
\text { National Investment } \\
\text { Funds (NIFs) }\end{array}$ \\
\hline $\begin{array}{l}\text { Corporate } \\
\text { governance of OCs }\end{array}$ & Perhaps by IFs & $\begin{array}{l}\text { By strategic investors } \\
\text { buying bulk of IPO }\end{array}$ & $\begin{array}{l}\text { By management of lead } \\
\text { NIF with controlling } \\
\text { block of OC shares }\end{array}$ \\
\hline Implementation & Completed & $\begin{array}{l}\text { Abandoned after small } \\
\text { trial }\end{array}$ & Underway \\
\hline $\begin{array}{l}\text { Relative importance } \\
\text { in the privatization } \\
\text { programme }\end{array}$ & Major & Minor & Major \\
\hline
\end{tabular}

\subsubsection{Implementation and relative importance in the privatization programme}

In the Czech Republic, the MP programme was successfully completed. It affected about 1,800 companies and covered about 40 per cent of the book value of state property divested (excluding physical restitution). ${ }^{14}$

The Hungarian SISOP was supposed to apply to shares in about 70 firms to be sold for a total value of about HUF 120 billion (about US\$ 1.3 billion at the average 1993 exchange rate). In April 1994, an experimental first round of two IPOs with SISOP participation, for a total value of HUF 4 billion, had a satisfactory response from investors. However, in the June 1994 parliamentary elections, the government coalition lost badly and the successor coalition (composed of former opposition parties) abandoned SISOP.

The Polish MPP is in progress. About 95 per cent of the eligible people bought MSCs. The over 500 OCs put into the programme accounted for more than 10 per cent of the total book value of all remaining state property (including assets the government does not intend to privatize). The lead NIF positions in the OCs have been distributed in a 15-round lottery, each with a different sequence in which the various NIFs chose OCs for which they would play the lead role. The Polish Anti-Monopoly Office prepared a list of companies in a particular industry whose lead shares could not be awarded to the same NIF, lest it acquire, through control of those OCs, a dominant position in the industry. Non-lead NIFs have begun to sell off their small positions in OCs. Lead NIFs have sold some OCs and are restructuring others to facilitate the sale of their shares. The exchange of MSCs into shares in the individual NIFs is expected by the end of 1997. 


\section{Conclusion}

The three countries have differed markedly in the use and results of the non-standard methods of restitution, management and employee buyouts and mass free transfer of assets in their national privatization programmes.

In the Czech Republic a government firmly committed to privatization has remained in power. It energetically carried out restitution by the physical return of expropriated property. Also, it successfully completed technically challenging voucher auctions to give a significant portion of state assets free to citizens, directly or through their chosen financial intermediaries. On the other hand, the government eschewed any special arrangements for EBOs or MBOs as unjustified favouritism.

Hungary has taken a gradual approach to privatization and, with serious deficits in the budget (and the balance of payments), has preferred to sell state assets (including to foreign investors) rather than distribute them free. Also, privatization measures have been stalled or reversed after elections ousted the ruling coalition of political parties. Hungary adopted limited programmes for restitution, MEBOs and mass privatization, which subsequently were weakly implemented or even abandoned.

Poland has experienced strong controversies about privatization, as well as changes in government after electoral defeats. No restitution programme has been approved. A relatively large number of small SOEs was privatized through lease-purchase MEBOs. A major MP programme was presented to Parliament in 1991, but not enacted into law until 1993 and implementation did not begin until late 1995. It is too soon to assess the results.

\section{Endnotes}

1. Research for this study was supported in part by a grant from the International Research and Exchanges Board, with funds provided by the US Department of State (Title VIII) and the National Endowment for the Humanities and, in part, by a grant from the Office of the Vice-President for Research at the University of Michigan. None of these organizations is responsible for the views expressed. I gratefully acknowledge the assistance of numerous economists and officials who kindly supplied me with information during a research trip to the Czech Republic. Hungary and Poland. The citation 'interview' refers to such information. For helpful comments, I thank Judit Karsai, Ivan Major, Michal Mejstrik, Péter Mihalyi, Ryszard Rapacki and two anonymous referees.

2. On January 11993 , the former Czechoslovakia split into the Czech Republic and the Slovak Republic. This study considers privatization in Czechoslovakia before the split and in the Czech Republic afterwards. Since the split, privatization efforts have been much more modest in the Slovak Republic than in the Czech Republic.

3. The paper does not discuss these countries' use of standard, and thus less interesting, methods of divestiture of state assets, such as initial public offerings (IPOs), auctions and public tenders.

4. Restitution is sometimes inaccurately called 'compensation' or 'reprivatization'. 'Compensation' excludes redress by return of physical property. 'Reprivatization' (a) could include the divestiture of expropriated assets even if they were not improperly nationalized; (b) could include the sale of nationalized property to 
others than the original owners; and (c) excludes financial compensation instead of the return of physical property.

5. However, it is possible to seek redress under a section of the Code of Administrative Procedure covering invalid administrative decisions. Some applications have been approved, but state-owned enterprises (SOEs) often refuse to surrender the real-estate involved.

6. In the Czech Republic and Hungary legislation separate from the restitution programme returned some confiscated property to religious and charitable institutions.

7. There was no significant conflict between restitution and mass privatization (MP). (a) Restitution applied chiefly to different (smaller) property than that in mass privatization. (b) Physical restitution started before mass privatization. (c) When financial compensation applied (see next endnote), it was provided in shares in a Restitution Investment Fund, to which the government allocated 3 per cent of the shares in companies included in MP.

8. These cases include the following: (a) The property cannot be returned because it has been destroyed. (b) Foreign capital participates in the entity holding the property covered by restitution. (c) The property has been improved since nationalization. In this case, the claimant may choose to accept financial compensation for the property originally confiscated, or to obtain physical restitution by paying the difference between the officially estimated values of the property before and after the improvement. The former option is usually selected.

9. EBOs, MBOs and MEBOs were not intrinsic components of 'spontaneous privatization' or 'self-privatization' in Hungary. 'Spontaneous privatization' (1988-90) was a misnomer because it was neither spontaneous nor privatization. Instead, it involved, with the full knowledge and consent of supervizing ministries, the conversion of some SOEs into a larger number of joint-stock companies (JSCs), without any change from state to private ownership. Under 'self-privatization' (1991-93), a consulting firm, chosen from a list drawn up by the State Privatization Agency (SPA), prepared a privatization project for an SOE, which was then submitted to the SPA for approval (Voszka, 1993). In a few cases, the project involved the sale of the SOE to a new limited liability company formed by the SOE's managers and employees. In addition, the equivalent of an MBO occurred when the SPA made lease-purchase arrangements with managers of SOEs that the SPA deemed unsaleable (Boda and Neumann, 1994).

10. The transformation of an SOE into a JSC, whose shares are initially entirely owned by the state, is sometimes misleadingly called 'commercialization.' This term implies that the JSC, unlike the SOE, will be run as a profit-seeking business. However, an SOE might be run on this basis and a JSC might not. Hence, 'corporatization' more accurately conveys that the transformation consists of a change in legal status (which may or may not be followed by changes in the ownership or behaviour of the enterprise).

11. Careful case studies do not support the possible hypotheses (a) that managers and employees usually bought only 'better-than-average' firms or (b) that they typically understated or concealed profits in order to drive down the price paid for the firm.

12. This burden, specific to buyouts, is in addition to high real interest rates for the enterprise sector in general, and the disadvantage of smaller versus larger firms in access to credit.

13. '... the underlying philosophy of the Czech privatization programme [is] that any 
[other] owner is better than the state. Even if some enterprises remain without effective owners for some time, the implications for managerial behaviour are not necessarily worse than if the enterprise remained in state-ownership' (Charap and Zemplinerova, 1994a, p.143).

14. Smaller units divested in their entirety by public auction, public tender, or direct sale represented 14.2 per cent of the total book value; larger units privatized as JSCs, 79.5 per cent; and units transferred free to municipalities, 6.3 per cent. In turn, the portion of the aggregate book value of JSC's allocated to voucher privatization was 50.7 per cent (Lieberman et al., 1995, p.71).

\section{References}

Blaszczyk, B. (1995), 'Various Approaches to Privatization in Poland, Their Implementation and the Remaining Privatization Potential', In: Quaisser et al., eds., Privatization (see below), Vol.1, pp.73-110.

Boda, D. and L. Neumann (1994), 'Employees as New Owners of Privatized Firms in Hungary', unpublished manuscript, Budapest: Research Institute of Labour.

Bouin, O. (1993), 'Privatization in Czechoslovakia,' In: Ramanadham, V. V., ed., Constraints and Impacts of Privatization, London: Routledge, pp.115-38.

Cepl, V. (1992), 'Restitution of Property in Post-Communist Czechoslovakia', In: Rayner, S. A., ed., Privatization in Central and Eastern Europe, London: Butterworths, pp.16-21.

Charap, J. and A. Zemplinerova (1994a), 'Key Issues in Restructuring the Czech Economy', In: Bohm, A. and U. Korze, eds., Privatization Through Restructuring, Ljubljana: Central and East European Privatization Network, pp.123-50.

Charap, J. and A. Zemplinerova (1994b), 'Management Buyouts in the Privatization Programme of the Czech Republic', Trends and Policies in Privatization, Vol.1(3), pp.141-60.

Comisso, E. (1995), 'Legacies of the Past or New Institutions? The Struggle Over Restitution in Hungary', Comparative Political Studies, Vol.28(2), July, pp.200-38.

'Compensation Scene' (1995), Privinfo, Vol.4(15), Hungarian Privatization and State Holding Company, August, pp.36-9.

Filatotchev, I., I. Grosfeld, J. Karsai, M. Wright and T. Buck (1996), 'Buyouts in Hungary, Poland and Russia: Governance and Finance Issues', Economics of Transition, Vol.4(1), May, pp.67-88.

Gomulka, S. and P. Jasinski (1994), 'Privatization in Poland, 1989-1993: Policies, Methods and Results', In: Estrin, S., ed., Privatization in Central and Eastern Europe, London: Longman, pp.218-51.

Karsai, J. (1994), 'Management Buyouts in Hungary', Industrial Enterprises and Regions in the Hungarian Transition, Budapest: Research Institute of Industrial Economics, Hungarian Academy of Sriences, pp.37-54.

Kotrba, J. and J. Svejnar (1994), 'Rapid and Multifaceted Privatization: Experience of the Czech and Slovak Republics', Moct-Most, Vol.4(2), pp.147-85.

KRP Project Management Group (1995), 'Small Investor Share-Ownership Programme', Mass Privatization: An Initial Assessment, Paris: Organization for Economic Cooperation and Development, pp.135-51.

Kwiecinski, T. and J. Baehr (1995), 'The Polish Dilemma of Restitution-Selected Legal Issues', In: Quaisser et al., eds., Privatization, Vol.2, pp.513-27. 
Lastovicka, R., A. Marcinèin and M. Mejstrik (1995), 'Corporate Governance and Share Prices in Voucher-Privatized Companies', In: Svejnar, J., ed., The Czech Republic and Economic Transition in Eastern Europe, San Diego, Calif:: Academic Press, pp.199-209.

Lieberman, I., A. Ewing, M. Mejstrik, I. Mukherjee and P. Fielder, eds. (1995), Mass Privatization in Central and Eastern Europe and the Former Soviet Union: A Comparative Analysis, Washington, D.C.: World Bank.

Major, I. (1994), 'The Constraints on Privatization in Hungary: Insufficient Demand or Inelastic Supply?', Moct-Most, Vol.4 (2), pp.107-45.

Mejstrik, M. and J. Burger (1994), 'Privatization in Practice: Czechoslovakia's Experience from 1989 to Mid-1992', In: Rondinelli, D. A., ed., Privatization and Economic Reform in Central Europe: The Changing Business Climate, Westport, Conn.: Quorum Books, pp.135-57.

Mihályi, P. (1994), 'Privatization in Hungary: An Overview', Privatization in the Transition Process: Recent Experiences in Eastern Europe, Geneva: United Nations Conference on Trade and Development; Budapest: Kopint-Datorg, pp.363-85.

Nemes, A. (1995), 'Application of the ESOP Law: An Interpretation', Privinfo, Vol.4(4), February, pp.34-43.

Pehe, J. (1994), 'Legal Difficulties Beset the Czech Restitution Process', RFE/RL Research Report, Vol.3(28), July 15, pp.6-13.

Quaisser, W., R. Woodward and B. Blaszczyk (1995), eds., Privatization in Poland and East Germany: A Comparison, Vols. 1 and 2, Working Papers No. 180 and 181, Munich: Osteuropa-Institut.

Rapacki, R. (1995), 'Privatization in Poland: Performance, Problems and Prospects', Comparative Economic Studies, Vol.37(3), Fall, pp.57-75.

Rapacki, R. (1996), 'Privatization and the Public Exchequer in Poland', unpublished manuscript.

Shafik, N. (1995), 'Making a Market: Mass Privatization in the Czech and Slovak Republics', World Development, Vol.23(7), July, pp.1,143-56.

Szomburg, J. and P. Tamowicz (1994), 'Employee and Management Buyouts in Polish Privatization', Trends and Policies in Privatization, Vol.1(3), pp.175-95.

Voszka, É. (1993), 'Escaping from the State-Escaping to the State: Managerial Motivation and Strategies in Changing the Ownership Structure in Hungary', In: Samogyi, L., ed., The Political Economy of the Transition Process in Eastern Europe, Brookfield, Vermont: Edward Elgar, pp.227-39.

Woodward, R. (1995), 'Management-Employee Buyouts in Poland and the Former GDR: A Comparison', In: Quaisser et al., eds., Privatization, Vol.2, pp.329-40. 